\title{
COMPARISON OF THREE DECONTAMINATION METHODS FOR MYCOBACTERIUM BOVIS ISOLATION
}

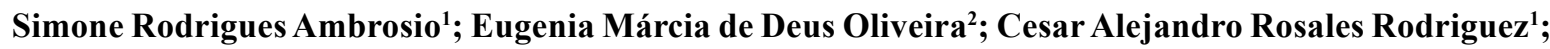 \\ José Soares Ferreira Neto'; Marcos Amaku ${ }^{1 *}$
}

${ }^{1}$ Departamento de Medicina Veterinária Preventiva e Saúde Animal, Faculdade de Medicina Veterinária e Zootecnia, Universidade de São Paulo, São Paulo, SP, Brasil; ${ }^{2}$ Universidade Federal da Bahia, Salvador, BA, Brasil

Submitted: July 11, 2007; Returned to authors for corrections: November 22, 2007; Approved: April 25, 2008.

\section{SHORT COMMUNICATION}

\begin{abstract}
Sixty samples of tissue fragments with lesions suggestive of tuberculosis from bovine abattoirs, kept in saturated solution of sodium borate, were subjected to four treatments: $4 \% \mathrm{NaOH}$ (Petroff Method), $12 \%$ $\mathrm{H}_{2} \mathrm{SO}_{4}$ and $1.5 \% \mathrm{HPC}$ (1-Hexadecylpyridinium Chloride) decontamination, and physiological saline solution (control). The HPC method showed the lowest contamination rate (3\%) when compared to control $(88 \%$, $\mathrm{p}<0.001), \mathrm{NaOH}(33 \%, \mathrm{p}<0.001)$ and $\mathrm{H}_{2} \mathrm{SO}_{4}(21.7 \%, \mathrm{p}<0.002)$. Regarding the isolation success, the HPC method was better (40\%) than the control ( $3 \%, \mathrm{p}<0.001), \mathrm{NaOH}(13 \%, \mathrm{p}=0.001)$ and $\mathrm{H}_{2} \mathrm{SO}_{4}(1.7 \%, \mathrm{p}<0.001)$ methods. These results indicate that HPC is an alternative to the Petroff method.
\end{abstract}

Key-words: Mycobacterium bovis, decontamination, Petroff, HPC

In Brazil, the official notification data on bovine tuberculosis indicate an average national prevalence of $1.3 \%$ of infected animals, from 1989 to 1998 . The Ministry of Agriculture, Livestock and Food Supply (MAPA), observing the inefficacy of recently adopted measures to control bovine tuberculosis (11), implemented the National Program for Tuberculosis and Brucellosis Control and Eradication (15).

Bovine tuberculosis control, traditionally, starts with strategies that aim at reducing the number of farms with infected animals, accomplished by certifying disease-free herds, which involves the use of massive indirect tests and sanitary measures when positive animals are detected. This procedure demands high investments, and significant reductions in the prevalence of infected herds are achieved in the medium and long run (14).

The transition to the eradication phase, whose aim is to eliminate all infected herds, is done by implementing a surveillance system. A good alternative is to use abattoir information as a basis for this system (1). In this case, tuberculosis lesions are obtained in abattoirs, sent to the laboratory and, after bacteriological confirmation of the disease, the farm is traced, tuberculin tests are performed and animals that are positive reactors are slaughtered. Thus, direct diagnosis, that is, isolation and identification of the $M$. bovis isolates, is of great importance to the system.

The bacteriological characterization of the infected herds, using abattoir information, is the basis of the system, and its sensitivity will depend upon the sensitivity of the isolation methods used. The best way to detect M. bovis in tissue fragments is by culturing decontaminated samples on Lowenstein-Jensen and Stonebrink Leslie solid culture medium (20), subsequently incubated at $37^{\circ} \mathrm{C}$ for up to 60 days (2).

The sample decontamination aim is to inactivate other bacteria that might be present in the sample, to avoid their faster growth and media nutrients exhaustion, which renders $M$. bovis growth unfeasible. One of the most used decontamination method in Veterinary Medicine is the Petroff method, that uses

*Corresponding Author. Mailing address: Departamento de Medicina Veterinária Preventiva e Saúde Animal, Faculdade de Medicina Veterinária e Zootecnia, Universidade de São Paulo, Av. Prof. Dr. Marques de Paiva, 87, CEP: 05508-270, São Paulo, SP, Brasil. Tel.: (+5511)3091-7653. Fax: (+5511) 3091-7928. E-mail: amaku@vps.fmvz.usp.br 
$4 \% \mathrm{NaOH}$ with posterior neutralization with $1 \mathrm{~N} \mathrm{HCl}$, which is applied, traditionally, in tissue fragments samples refrigerated or frozen $(3,18)$. Alternatively, these fragments may be immersed in a saturated solution of sodium borate. The advantage of this procedure is to provide conservation for two months, without the need of refrigeration or freezing, what makes it suitable to be used in any kind of slaughterhouse and also in field conditions. It is important to consider that the sample contamination rate may vary according to the kind of sample, the way it was collected and preserved, and also transporting time to the laboratory (6).

Besides the Petroff method, other substances have also been used for the same purpose: Sulfuric Acid (17), Oxalic Acid (OA) (5,13), Benzalconium Chloride (BC) (10), Trisodium Phosphate and Sodium Laurilsulfate (2), Sodium Chloride (9), and the equivalent 1-Hexadecylpyridinium Chloride (HPC) or Cetylpyridinium Chloride (CPC) $(12,19)$.

The method traditionally used to isolate $M$. bovis from bovine tissues is the Petroff method, considered sensitive and relatively cheap (2). The $0.75 \%$ HPC and the $6 \%$ Sulfuric Acid presented low toxicity for M. bovis, AN5 strain (12). The Sulfuric Acid is the method used in the Brazilian reference laboratory for animal diseases (LANAGRO) (12). HPC does not require the neutralization stage, presenting a faster processing time.

The products used in the decontamination procedures must not be aggressive to the mycobacteria and, at the same time, be able to inactivate the accompanying microbiota. The balance of these two capabilities, together with the degree of sample contamination, will be the major responsible factor for the sensitivity of the isolation method.

Considering the impact that the decontamination methods might have upon the sensitivity of $M$. bovis isolation and the lack of information about the influence of the saturated solution of sodium borate on the contaminating microbiota, the present work aims at comparing three decontamination methods (Petroff, HPC and Sulfuric Acid) of tuberculosis suspicious samples from slaughtered bovines kept in saturated solution of sodium borate.

Sixty tissue fragments (lymph nodes and lungs), with lesions suggestive of tuberculosis, from sixty bovines condemned for tuberculosis during routine inspection in abattoirs were placed in $500 \mathrm{~mL}$ plastic vials and immersed in saturated solution of sodium borate. Laboratory processing did not exceed 60 days. Three grams of each lesion were homogenized with $10 \mathrm{~mL}$ of $0.85 \%$ physiological saline solution in a Stomacher for 1 minute. After that procedure, $1.0 \mathrm{~mL}$ aliquots were subjected to a control method $(0.85 \%$ saline solution) and three decontamination methods: modified Petroff (basic method) $(4,16)$, LowensteinJensen (acid method) (17), and HPC (7). In Figure 1, we can visualize a scheme of the methodology employed in the decontamination protocols.

After the aforementioned protocols were performed, each one of the samples was subjected to the same technical sequence, constituted of: centrifugation at 2,500 r.p.m. for 20 minutes, the supernatant was discarded, the pellet resuspended in $1.0 \mathrm{~mL}$ of sterile $0.85 \%$ physiological saline solution, and homogenization followed by duplicate inoculation (two tubes) of $100 \mu \mathrm{L}$ onto Stonebrink Leslie medium, as shown in Fig. 1. The tubes were incubated at $37^{\circ} \mathrm{C}$, layed at $30^{\circ}$ angle, and the screw-caps were kept half open until media surfaces were completely dry. After that, they were incubated at horizontal position and daily observed for the presence of contaminants during the first week. Then, presence of contamination and acid-fast bacilli isolation were checked in weekly observations carried out until 90 days of incubation.

The comparisons of the proportions of Mycobacterium bovis isolation successes among the decontamination methods and among these and the control method were performed by the $\chi^{2}$ test. The proportions of failures (contaminations) were also compared using the same methodology. The program Minitab 14 (Minitab Inc.) was used for the statistical analysis.

The HPC showed the smallest contamination proportion $(3 \%)$, with a statistically significant difference compared to the control group (88\%, $<<0.001), \mathrm{NaOH}(33 \%, \mathrm{p}<0.001)$ and $\mathrm{H}_{2} \mathrm{SO}_{4}$ $(21.7 \%, \mathrm{p}=0.002)$. Comparing the proportions of isolation successes, the HPC showed the best result (40\%), statistically different from the control group ( $3 \%, \mathrm{p}<0.001), \mathrm{NaOH}(13 \%$, $\mathrm{p}=0.001)$ and $\mathrm{H}_{2} \mathrm{SO}_{4}(1.7 \%, \mathrm{p}<0.001)$. Fig. 2 shows the isolation

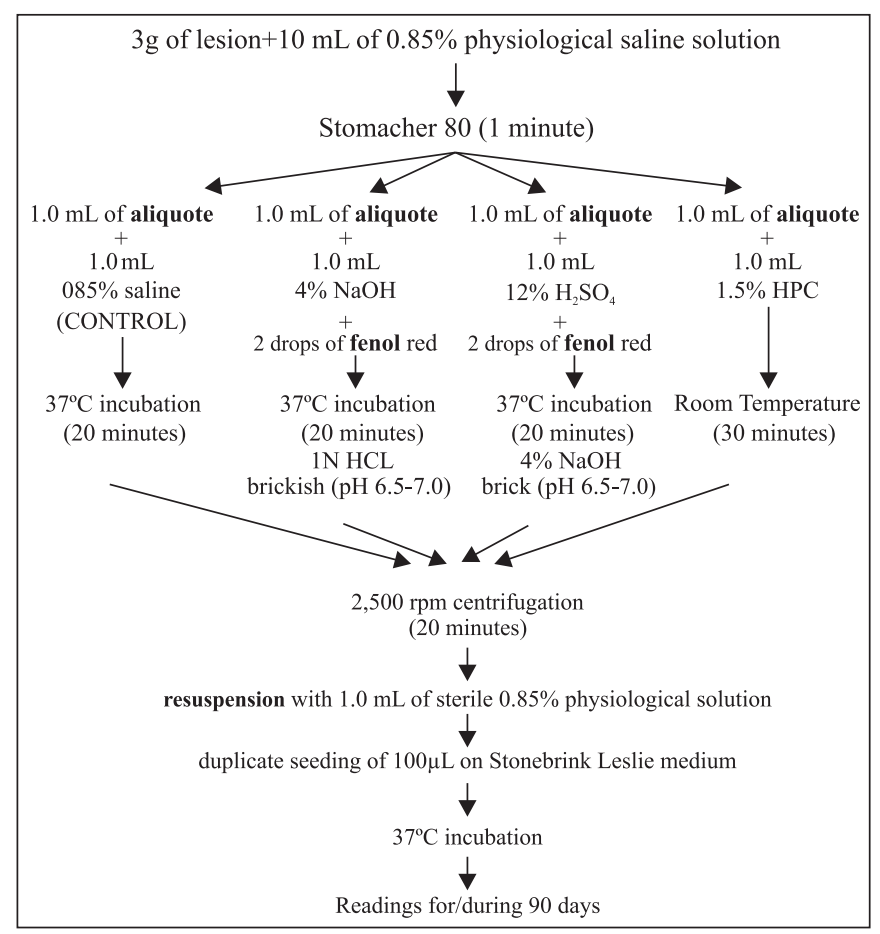

Figure 1. Scheme of the decontamination protocols used in organ homogenates to isolate Mycobacterium bovis. 


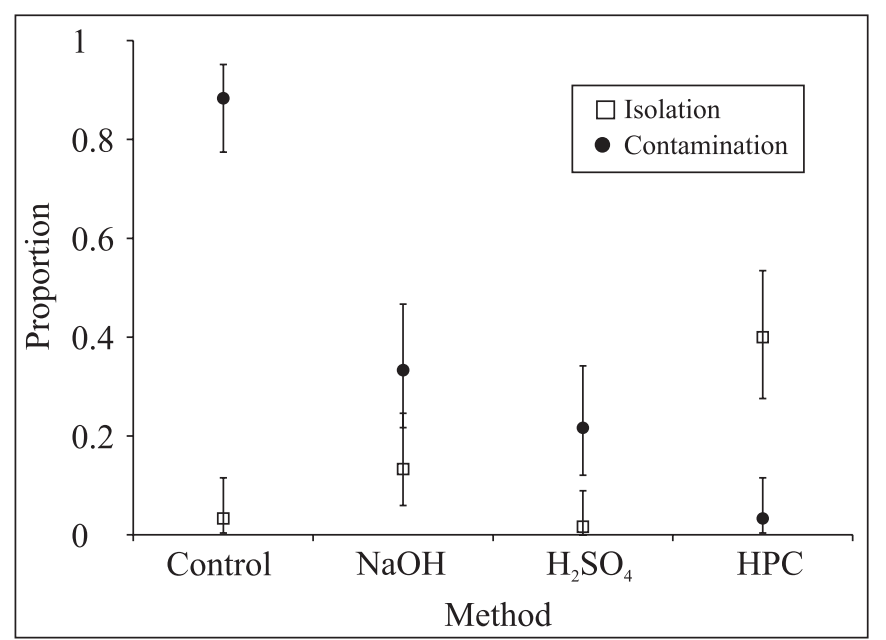

Figure 2. Proportions of Mycobacterium bovis contamination (dots) and isolation (squares) for the three different decontamination methods and the control group. Error bars show a $95 \%$ confidence interval for the proportion.

and contamination proportions for the three different methods and the control group. The HPC was the most adequate method for recovering Mycobacterium bovis from bovine tissues preserved in saturated solution of sodium borate.

Corner et al. (8), evaluating four decontamination methods, in different concentrations, observed similar results for $M$. bovis isolation from bovine tissue artificially contaminated with AN5 strain. The most efficacious decontaminants concentrations were: $0.75 \% \mathrm{HPC}, 5 \% \mathrm{OA}, 0.25 \% \mathrm{BC}$ and $2 \% \mathrm{NaOH}$. As, in the present study, HPC was used in a concentration of $1.5 \%$, it is possible that even better results may be obtained using a concentration of $0.75 \%$.

Holanda et al. (12) tested four different decontamination methods - $0.75 \% \mathrm{CPC}, 0.25 \% \mathrm{BC}, 5 \% \mathrm{OA}$ and $6 \% \mathrm{H}_{2} \mathrm{SO}_{4}-$ in bovine lymph nodes artificially contaminated with AN5 strain. The decontaminants $6 \% \mathrm{H}_{2} \mathrm{SO}_{4}$ and $0.75 \%$ CPC yielded the best results, due to the lower toxicity presented. These authors obtained similar results for $\mathrm{HPC}$ and $\mathrm{H}_{2} \mathrm{SO}_{4}$, what differs from our results. It is important to stress that the $\mathrm{HPC}$ and $\mathrm{H}_{2} \mathrm{SO}_{4}$ concentrations used by Holanda et al. (12) were $0.75 \%$ and $6 \%$, respectively. Besides, these authors did not mention the conservation procedure for the lymph node samples, which were artificially contaminated with $M$. bovis. In the present study, positive samples were from naturally infected animals.

Evaluating the primary isolation of $M$. bovis from bovine lesions, Corner and Trajstman (7) verified that $0.75 \%$ HPC was as efficient as $2 \% \mathrm{NaOH}$ in controlling contaminants growth. A faster processing time is the advantage of $0.75 \% \mathrm{HPC}$ over $\mathrm{NaOH}$, due to the fact that HPC does not require the neutralization stage, so it might be less toxic to M. bovis.
Therefore, it speeds up the isolation and favors early development of colonies. In the present study, we observed early formation of colonies and a more abundant growth in the samples decontaminated with HPC. It must be pointed out that the isolation velocity was not measured in the present study.

Thus, to isolate $M$. bovis from naturally infected bovine samples kept in saturated solution of sodium borate, the $1.5 \%$ HPC decontamination method presented a proportion of isolation higher than the proportions observed for $12 \%$ sulfuric acid and $4 \% \mathrm{NaOH}$.

\section{ACKNOWLEDGEMENTS}

The authors acknowledge CNPq for the financial support.

\section{RESUMO}

\section{Comparação de três métodos de descontaminação para isolamento de Mycobacterium bovis}

Sessenta amostras de fragmentos de tecidos com lesões sugestivas de tuberculose provenientes de abatedouros bovinos, conservadas em solução saturada de borato de sódio, foram submetidas a quatro tratamentos: descontaminação através dos métodos $\mathrm{NaOH} 4 \%$ (Método Petroff), $\mathrm{H}_{2} \mathrm{SO}_{4} 12 \%$ e HPC (Cloreto de hexadecilpiridínio) 1,5\%, e solução salina (controle). O método HPC apresentou a menor proporção de contaminação $(3 \%)$, em relação ao controle $(88 \%, \mathrm{p}<0,001)$, $\mathrm{NaOH}(33 \%, \mathrm{p}<0,001)$ e $\mathrm{H}_{2} \mathrm{SO}_{4}(21,7 \%, \mathrm{p}=0,002)$. Em relação ao sucesso no isolamento, o método HPC apresentou o melhor resultado (40\%), em relação ao controle $(3 \%, \mathrm{p}<0,001), \mathrm{NaOH}$ $(13 \%, p=0,001)$ e $\mathrm{H}_{2} \mathrm{SO}_{4}(1,7 \%, \mathrm{p}<0,001)$. Os resultados indicam que o HPC é uma alternativa à utilização do método Petroff.

Palavras-chave: Mycobacterium bovis, descontaminação, Petroff, HPC

\section{REFERENCES}

1. Brown, W.; Anda, J.H. (1998). Tuberculosis in adult beef cattle of mexican origin shipped direct-to-slaughter into Texas. J. Am. Vet. Assoc., 212 (4), 557-559.

2. Centro Panamericano de Zoonosis. (1973). Bacteriologia de la tuberculosis humana y animal (Série de monografias cientificas y tecnicas, 11). Centro Panamericano de Zoonosis, Buenos Aires.

3. Centro Panamericano de Zoonosis. (1972). Diagnóstico de laboratório de la tuberculosis animal (Nota tecnica, 6). Centro Panamericano de Zoonosis, Buenos Aires.

4. Centro Panamericano de Zoonosis. (1979). Métodos de laboratório de microbiologia veterinária para el aislamiento e identificacion de micobacterias (Série de monografias cientificas y tecnicas, 6). Centro Panamericano de Zoonosis, Buenos Aires.

5. Claxtron, P.D.; Eamens, G.J.; Mylrea, P.J. (1979). Laboratory diagnosis of bovine tuberculosis. Aust. Vet. J., 55, 514-520. 
6. Corner, L.A. (1994). Post mortem diagnosis of Mycobacterium bovis infection in cattle. Vet. Microbiol., 40 (1-2), 53-63.

7. Corner, L.A.; Trajstman, A.C. (1988). An evaluation of 1Hexadecylpyridinium Chloride as a decontaminant in the primary isolation of Mycobacterium bovis from bovine lesions. Vet. Microbiol., 18, 127-134.

8. Corner, L.A.; Trajstman, A.C.; Lund, K. (1995). Determination of optimum concentration of decontaminants for primary isolation. New Zeal. Vet. J., 43, 129-133.

9. David, H.; Brum, L.; Prieto, E. (1994). Manual de micobacteriologia em Saúde Pública. Princípios e métodos. Instituto de Higiene e Medicina Tropical, Lisboa.

10. Ellsworth, S.; Kirkbride, C.A.; Johnson, D.D. (1980). Excretion of Mycobacterium avium from lesions in the instestine and tonsils of infected swine. Am. J. Vet. Res., 41 (9), 1526-1530.

11. Ferreira Neto, J.S.; Bernardi, F. (1997). O controle da tuberculose bovina. Higiene Alimentar, 11 (47), 9-13.

12. Holanda, E.D.; Lobato, F.C.F.; Mota, P.M.P.C.; Abreu, V.L.V. (2002). Avaliação de métodos de descontaminção para isolamento de Mycobacterium bovis. Rev. Bras. Med. Vet., 24 (2), 54-57.

13. Jorgensen, J.B. (1982). An improved medium for culture of Mycobacterium paratuberculosis from bovine faeces. Acta Vet. Scand., 23 (3), 325-35.

14. Kantor, I.N.; Ritacco, V. (1994). Bovine tuberculosis in Latin America and the Caribbean: current status, control and eradication programs. Vet. Microbiol., 40 (1-2), 5-14.
15. Lage, A.P.; Roxo, E.; Müller, E.; Poester, F.; Cavalléro, J.C.M.; Ferreira Neto, J.S.; Mota, P.M.P.C.; Gonçalves, V.S.P. (2006). Programa Nacional de Controle e Erradicação da Brucelose e da Tuberculose Animal (PNCEBT). Manual Técnico. Ministério da Agricultura, Pecuária e Abastecimento, Brasília.

16. Pinheiro, S.R.; Vasconcellos S.A.; Ito, F.H.; Ferreira Neto, J.S.; Morais, Z.M. (1992). Influência da matéria orgânica na atividade micobactericida de cinco desinfetantes de uso pecuário. Braz. J. Vet. Res., 29 (1), 51-60.

17. Román, M.C. (1990). Microbiologia clinica de las enfermidades por micobactérias (tuberculosis, lepra e micobacteriosis). Faculdad de Medicina, Universidad de Córdoba, Espanha.

18. Rosemberg, J.; Tarantino, A.B.; Paula, A. (1990). Tuberculose. In: Tarantino, A.B. (ed.) Doenças pulmonares. 3. ed., Guanabara Koogan, Rio de Janeiro, p.233-297.

19. Smithwick, R.W.; Stratigos, C.B.; Davis, H.L. (1975). Use of Cetylpyridinium chloride and sodium chloride for decontamination of sputum specimens that are transported to the laboratory for the isolation of Mycobacterium tuberculosis. J. Clin. Microbiol., 1 (5), 411-413.

20. Wayne, L.G.; Kubica, G.P. (1986). The mycobacteria. In: Sneath, P.H.A.; Sharpe, M.E.; Holt, J.G. (eds.) Bergey's Manual of Systematic Bacteriology. 8. ed., Willians e Wilkins, Baltimore, v. 2, chap. 6, p.1435-1457. 